\title{
Development of Sharing Task and Jumping Task in Direct Proportion using Lesson Study and PBL
}

\author{
Elisa Mayang Sari, Ratu Ilma Indra Putri \\ Universitas Sriwijaya, Jl. Masjid Al Gazali, Bukit Lama, Palembang, Sumatra Selatan, Indonesia \\ e-mail: ratu.ilma@yahoo.com
}

\begin{abstract}
This Research's purpose is producing questions/case study in direct proportion topic focused on Map and Model, and analyse students' answer in solving these arranged questions through lesson study for learning community (LSLC) and PMRI approach using problem based learning (PBL) method. Research subject are students of grade VII of Junior High School 1 Palembang. From this research, it results a LKPD questions about direct proportion in Map and Model that consist of three cases, such as determine new scale from known scale in problem solving (C2), determine size of Limas House miniature from known scale and sizes in problem solving (C3), and check for errors from a given comparison in problem solving (C4). Based on the results of the analysis of Students answer small group, the average score obtained by students in problem 1 (sharing task) is 73.5, problem 2 (sharing task) average student score is 55, and average student score in problem 3 (jumping task) is 48.5. So these three problems are well-billed and can be used to the next stage of the field test.
\end{abstract}

Keywords: Proportion, PMRI, LSLC, PBL, Collaborative Learning

How to Cite: Sari, E.M. \& Putri, R.I.I. (2019). Development of Sharing Task and Jumping Task in Direct Proportion using Lesson Study and PBL. International Journal on Emerging Mathematics Education, 3(2), 177-190. http://dx.doi.org/10.12928/ijeme.v3i2.13865

\section{INTRODUCTION}

Students mostly looked at mathematics such with negative perception such as mathematics is a science with full of symbols and formulas which make students often confuse so that subject gives an unhappy experience of learning (Widyastuti, et.al., 2019). Students is lack of being pushed to improve their thinking ability in learning process and students did given directions to use and memorize formulas (Hasanah, et.al., 2019). Those problem make this subject as terrifying subject for students and make their less attention and curiosity of it (Patahuddin, et.al.,2009).

Material about direct proportion is one of the material felt difficult by students due lack of understanding how to apply it in the form of case study questions (Suwarni, 2017). But it is important for them to learn that which one of the basic in learning math, science and can useful in the real world as well as various situations in daily life (Utari, et.al., 2015). Map and model topic is one part of direct proportion material in mathematics related to all activities of counting in fractions, geometry, congruence, etc. (Dole, et.al., 2009; Utari, et.al., 2015). Sclae is relative comparison between object and proportion is relationship of size and scale in a composition (Dole, et.al., 2009)

One of the factors students feel difficulties in the proportion material, such as students do not understand the concept of how to calculate proportion and scale material that were taught at the elementary school level (Suwarni, 2017). Students will easier to understand contents of the question if students are trained to translate 
and interpret what is being asked in that (Suwarni, 2017). Students will easier to understand in complicated and abstract concepts if they have been given with concrete examples fit with the situations and conditions faced by experience or practice themselves (Suwarni, 2017).

Every concept in math is interrelated and a concept will be a precondition for other concepts that will be more useful if students build it themselves (Rosalina, 2019). Students can be understood if they can build using their experiences by making cognitive connections between new experiences and their previous mathematical understanding so that learning mathematics is not just memorizing formulas or theories (Gazali, 2016).

It is expected that all teachers act as facilitators for their students, besides that teachers are also required to be more creative in improving new learning skill so that is possible for students can express themselves through fun activities and can be able to develop (Primadiati, et.al., 2017).

To create a suitable learning environment, it need two things, such as a nonsocial environment consist of facilities, infrastructure, resources, and learning media. Second, there is a social environment in the form of student relationships with friends, with teachers, with school members (Widyastuti, et.al., 2019) Factors that can affect student learning such as, internal factors which are factors that influence learning outcomes from students such as psychological conditions and physiology of students, then external factors are factors related to the environment such as learning design (Hapsari, et.al., 2019).

To educate all students can be achieved through the design and application of suitable learning methods so as to create a learning environment (atmosphere) which makes students active, can facilitate the improvement of intelligence and selfpotential, and also the improvement of student soft skills that can be useful in social life (Widyastuti, et.al., 2019). However, currently learning method in Indonesia is too monotonous with one conventional method so that made many setbacks in learning mathematics (Lakkiran, et.al., 2015).

The learning method is a way of teaching that has been arranged based on the system used by teachers while learning and underlies the activities of the teacher and students to achieve the learning objectives (Widyastuti, et.al., 2019). The collaborative learning method is one of the learning methods focused to help the success of learning activities (Hasanah, et.al., 2019). The collaborative learning method can help students to learn respect the opinions of others and can improve their critical and rational of thinking so it make easier for students to learn and work together (Dayana, et.al., 2015 ; Paryanto, 2010).

In addition of the suitable learning method, the suitable learning model is also needed because it is important to improve the ability of students focused on obtain the knowledge that has been given by their educators (Basaria, et.al., 2018). Learning model is one way to overcome the problem of learning difficulties and understanding concepts (Fiana, et.al., 2019). Learning models relevant to the 2013 curriculum including problem based learning model (Problem Based Learning) which is one of the learning models that is considered capable of improving student learning outcomes (Fiana, et.al., 2019).

The problem based learning (PBL) model is one model that is able to develop and improve student creativity by giving students to real problems so students can compile their own knowledge, develop their skills, independent and their selfconfidence in solving problems on their own (Fiana, et.al., 2019). The characteristic of

IJEME, Vol. 3, No. 2, September 2019, 177-190. 
the PBL model is using problems in real life as material for students must learn in order to train, improve critical thinking skills, problem solving and gain knowledge and important things (Fiana, et.al., 2019).

PBL model is a learning model that uses case study in real life. By using the learning model, students will easily understand the concept of direct proportion material if accompanied by problems that are fit to the situation students have been faced (Suwarni, 2017).

To use this model, the suitable learning focused on student-centered approach can be used is Pendidikan Matematika Realistik Indonesia (PMRI) approach. PMRI is an innovation in mathematics teaching in Indonesia (Putri, et.al., 2015). It has been initiated by a group of teacher, educators and mathematicians since 2001 and up until now, many efforts have been carried on by the PMRI team to develop mathematics education in Indonesia included South Sumatera (Putri, et.al., 2015; Sembiring, et.al., 2010). The PMRI has been applied widely in mathematics' learning, start from the elementary to university level in the form of lectures, researches, and community services (Putri, et.al., 2015).

PMRI is an adaptation of RME, where in this learning program, the aim is starting from the real life for students so it can encourage them to be attached in the situation (Wahyuni, et.al., 2017). PMRI is a human and mathematical activity that significantly connected to the context of daily life as a source of development and as an application area through a process of mathematical both horizontal and vertical (Zulkardi, 2002). The context is also useful for students in establishing explicit relationships with mathematical ideas to support students' development in mathematical thinking (Utari, et.al., 2015). The material in this program has employed with local-culture contexts which experientially real for students. Using these, the students would not focus to learn directly into formulas (Putri, et.al., 2015). Some of the main principles in PMRI are guided and progressive mathematical discoveries, educational phenomena, and independent development models (Zulkardi, et.al., 2010). In addition, there are five characteristics in the PMRI approach. There are using contextual problems, using various models, student contributions, interactivity, and linkages (Zulkardi, et.al., 2010). Classroom activities which is being designed by the teachers also encourage students in group and classroom discussions (Putri, et.al., 2015).

However, due low quality of teachers and lack of creativity make it difficult for students to absorb the material that already delivered maximally so that become one of the causes low student mathematics learning outcomes happened (Supriyanto, et. al., 2015). If a teacher wants to design a good learning, one of the ways is to collaborate with other teachers to design (plan), try (do), observe and reflect (see) on the learning has been done, there will be many improvements that are not will directly improve the quality of learning by redesigning (Lewis, 2004)

Lesson study for learning community (LSLC) is a model of educational profession through collaborative and continuous learning based on the principle of mutual learning and collegiality to build learning communities, where lesson study is not a method or learning strategy, but lesson study activities can be applied in various learning methods or strategies, it need to be observed based on the situation, conditions, and problems faced by the teacher (Octarina, et.al., 2018).

For students, LSLC is a collaborative learning process focused on divided into groups and they support each other to make progress for each individual specifically and the achievement of the whole group in general (Sato, 2014). LSLC is usually organized into two stages of collaborative learning in learning, such as the level of the 
textbook (sharing task) and the advanced level (jumping task) that can embrace all levels of student ability in the class and can create mutual respect for each other because they share their own opinion (Asari, 2017).

Sharing task is a task given when learning takes place using problems form the level of understanding a concept or task that students are still able to solve it (Asari, 2017). A problem can be said as sharing tasks if students can understand the material about $50 \%$ of the total number of students in the class. Jumping task is a task given when learning takes place by using problems that can develop students 'high-level thinking skills, one of them is critical thinking, besides using that will be able to create learning activities among students such as dialogue, interaction which can develop students' communication skills and creating effective collaboration among fellow students (Putri, 2018 ; Sato, 2014).

In addition, learning should also be designed so it can meet the demands of the 21st century world so that generations of Indonesian can compete in future. To be able to compete, Indonesia education needs skills known as 4C skills in the 21st century (creativity and innovation; critical thinking and problem solving skills; communication skills; and collaboration). These skills are in suitable with the 2013 curriculum objectives which not only provides material to students, but also mastery of skills that require a high level of thinking (HOTs) from students (Kemdikbud, 2013; Kemdikbud, 2013; Putri, 2018).

From the things above, by designing the learning of direct proportion material on maps and models topic can improve the quality of learning on the material and provide solution for the difficulties faced by students so far because the teacher themselves is designing the learning. In designing good learning must require teachers who are creative and experts in their fields, teachers will find it difficult to design their own learning without the help of others.

LSLC is a learning system to manage teachers to work together in design learning on direct proportion material of maps and models topic by fusing the thoughts of teachers to create good quality learning. One of the causes of students' difficulties in direct proportion material on maps and models topic is because students have difficulties in understanding the concepts of proportion and scale that teachers tend to give abstractly by using formulas, sample problems, and exercises so that make difficult for students to solve problems if they get different problems. To overcome this situation, right approaches, models and learning methods are needed so it can be used in learning direct proportion material of maps and models topic.

The suitable learning approach on direct proportion material of maps and models topic is PMRI, where in the approach learning uses real contexts that student have been experienced or practicing themselves so it make students actively contribute so as to support students' mathematical thinking abilities. The suitable learning model used in direct proportion material of map and model topic is a PBL learning model that uses real context in learning so that it will be fit with the PMRI approach. The learning model uses problems with real context for students. By using the learning model, students are expected to develop the concept of direct proportion material of map and model topic into problems that require students' higher thinking abilities. The level of problems given during learning using the PBL model consists of two stages of the learning level in the LSLC system, such as sharing task stage or problems given to students with low level questions (C1-C3) and then the jumping task stage for questions with difficult level (C4-C6) which is expected by students so they can work together and discuss each other in solving these problems so that there

IJEME, Vol. 3, No. 2, September 2019, 177-190. 
are no more students do not learn in their class because they are not capable to participate in learning those.

The suitable learning method used in direct proportion material of map and model topic is collaborative learning that aims to enable students to be active in working together, help each other and respect each other's opinions while learning. The purpose of this study is to produce LKPD questions for students which can help their understanding of direct proportion material of map and model topic using the LSLC learning system and PBL learning models.

\section{RESEARCH METHOD}

This research uses design research method which is a form of qualitative approach. The stages in the design research type of development study/design research (Akker, 1999). Development study conducted are the preliminary stage which is to implement the initial idea of the literature study before designing the learning activities; and the formative evaluation stage which includes self-evaluation aimed at researchers to evaluate and examine the initial prototypes themselves, prototyping (expert reviews, one-to-one, and small groups) which aims to validate each prototype in terms of content, structure, and language (Tessmer, 1993; Zulkardi, 2002).

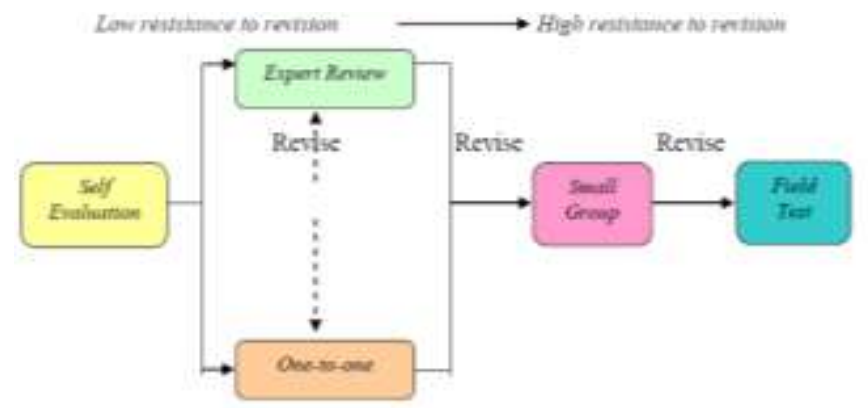

Figure 1. Plot Design formative Evaluation (Tessmer, 1993; Zulkardi, 2002)

In this study the development of professionalism that uses lesson study are plan, do, and see. The study was conducted in seventh grade students of SMP N 1 Palembang with direct proportion material of map and model topic. This study involved 8 students in a small group. The research took place over several weeks.

\section{RESULTS AND DISCUSSION}

Research conducted in some steps, such as :

1. Research Agenda 


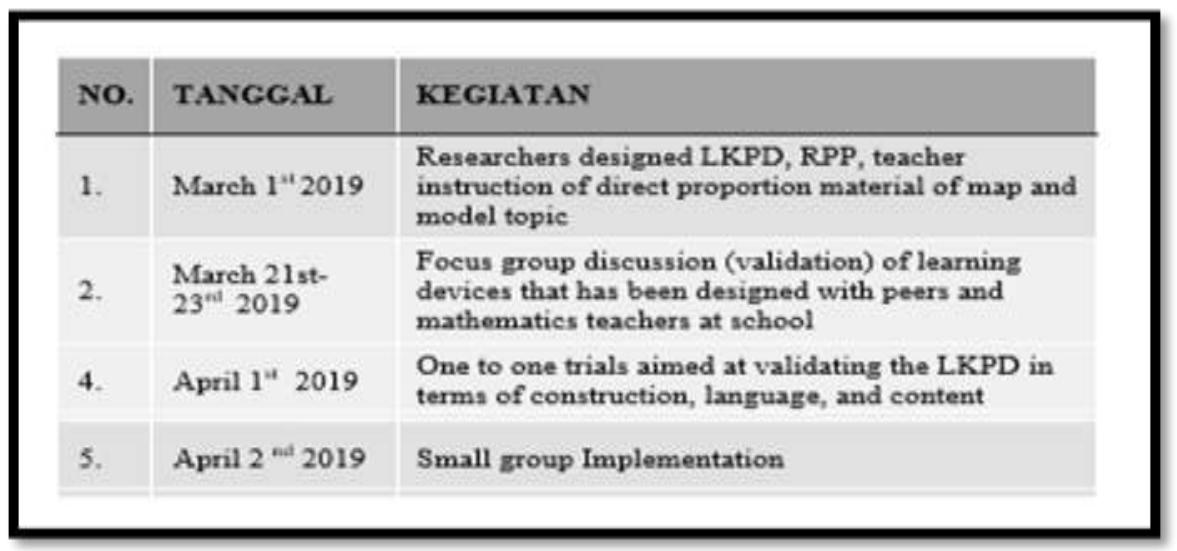

Figure 2. Research Activity Schedule

2. Researchers prepare LKPD, RPP, Teacher's instructions

Researchers discuss with the teacher at SMP N 1 Palembang about the material to be designed. Then from the discussion, the researcher got information that the VII grades in second semester had understood the concept of direct proportion material of map and model topic so the next step is the researcher need to design questions or problems in the form of case study.

3. LKPD Validation / Discussion with colleagues and mathematics teachers

Researcher designs LKPD questions that contain problems and then validate the LKPD with colleagues and math teachers to get information on whether LKPD is right and could be understood by students in terms of structure, content and language. The results of the validation will be considered by researchers either to make revisions or not. The results of changes at this stage include improvements of writing in the front page (semester information, work time, and learning objectives) and the level of difficulty of the LKPD consist of easy-medium-hard level.

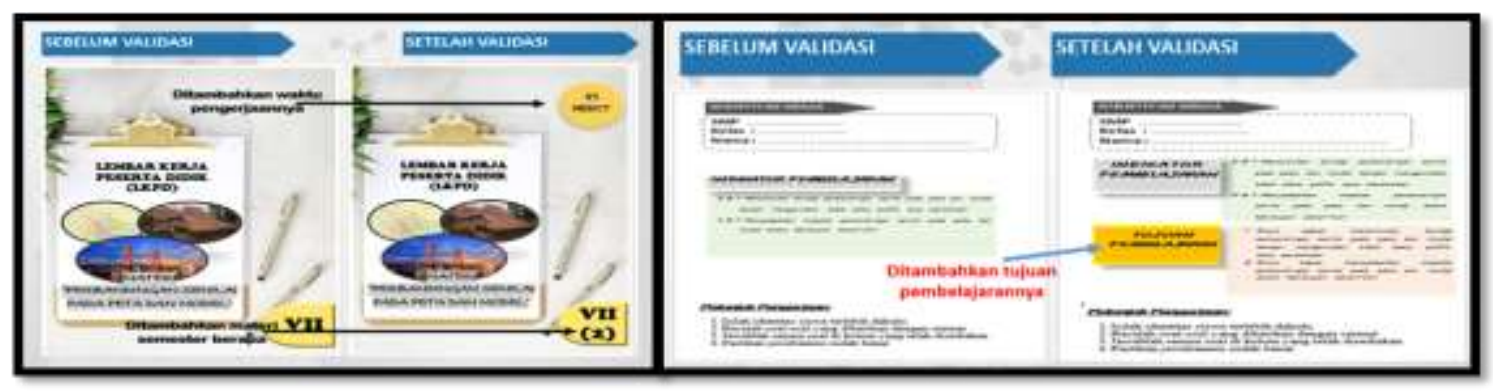

Figure 3. LKPD before and after validation with teachers and colleagues

4. Prediction answers of students with researchers, colleagues and math teachers

Researchers along with colleagues and math teachers predict the possibility of student answers ranged from low ability, medium ability, and high ability. It is needed to design so researchers can plan scaffolding if something happens that has been predicted beforehand. 


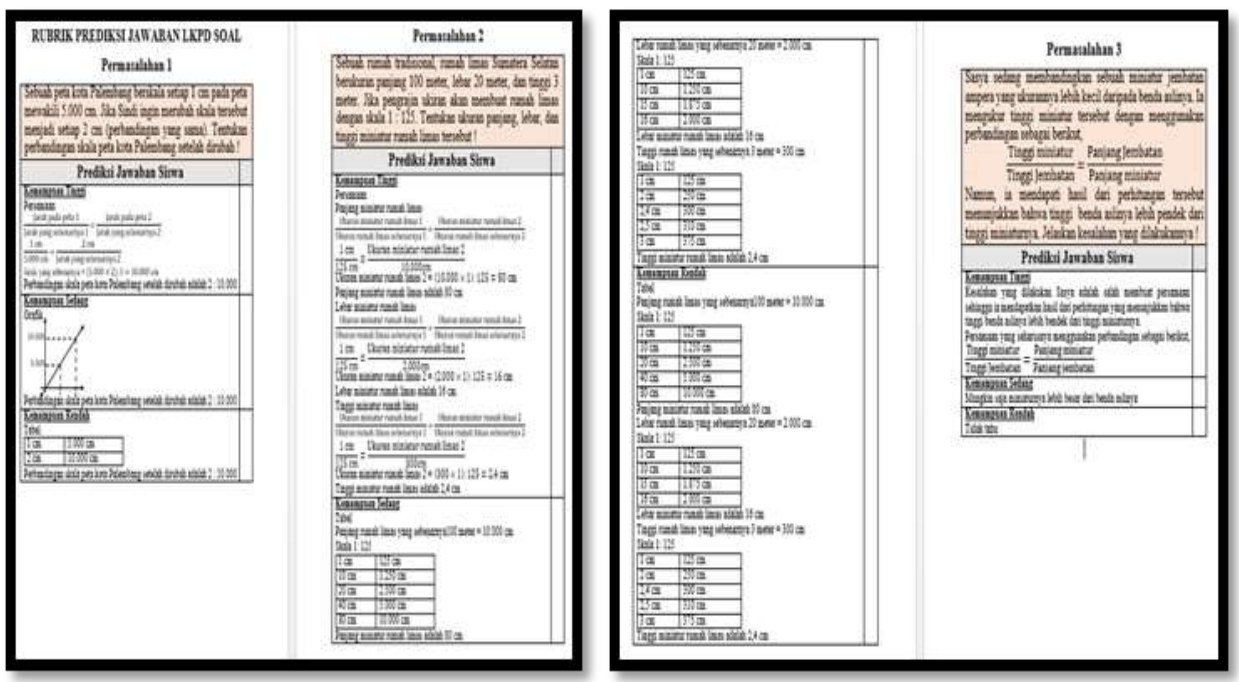

Figure 4. Answer prediction results together with teachers and researchers

\section{One to One}

The LKPD questions which already designed are being tested on 3 students with different levels of ability from the non-research subject class, students with high, medium and low abilities. Students are also expected to contribute by validating the LKPD in terms of language level and their understanding the purpose of the questions in LKPD. After that, the results of students' answers are analyzed and students are interviewed in focused on the work process of LKPD that has been done.

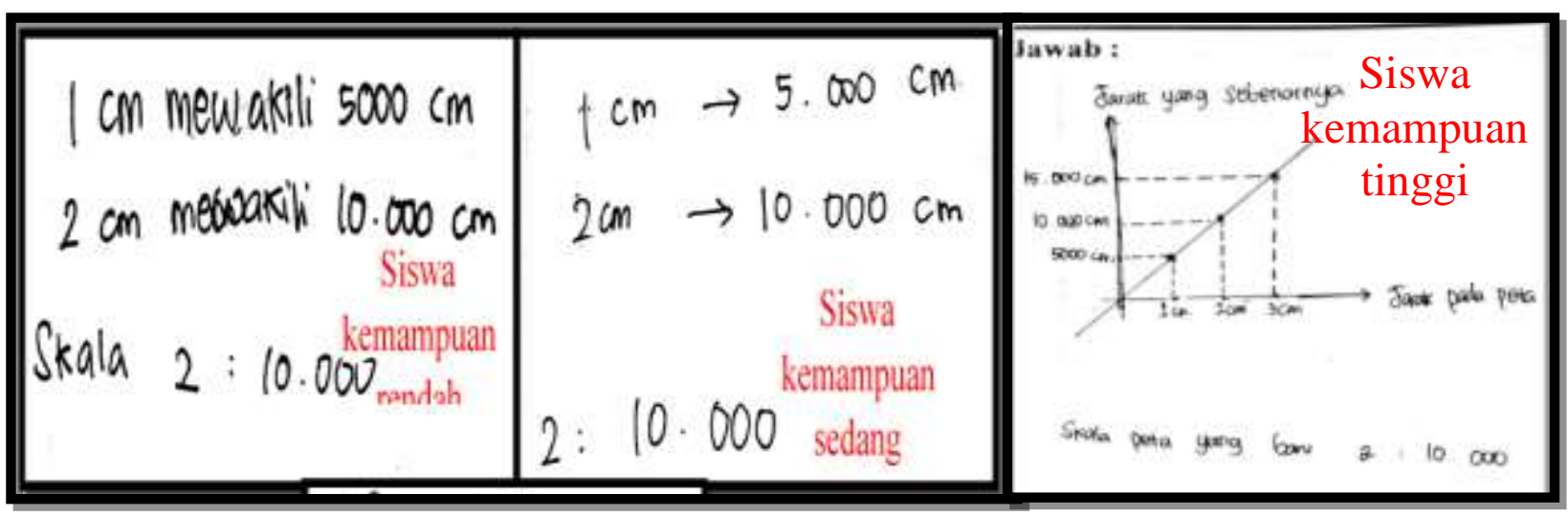

Figure 5. Results of student answers to problem 1

In the Figure 5, high, medium, and low ability students can answer the question correctly. Which is to measure the ability of students to understand the concepts and ask students to interpret into new statements. This problem in bloom taxonomy level is called a matter of understanding (C2) and also called a problem of sharing tasks because all students can answer correctly. The three abilities of students have various and correct answers such as low ability students solve the problem through sentences, students' ability to solve the problems with the arrow symbol, and high ability students solve the problems using graphics. 


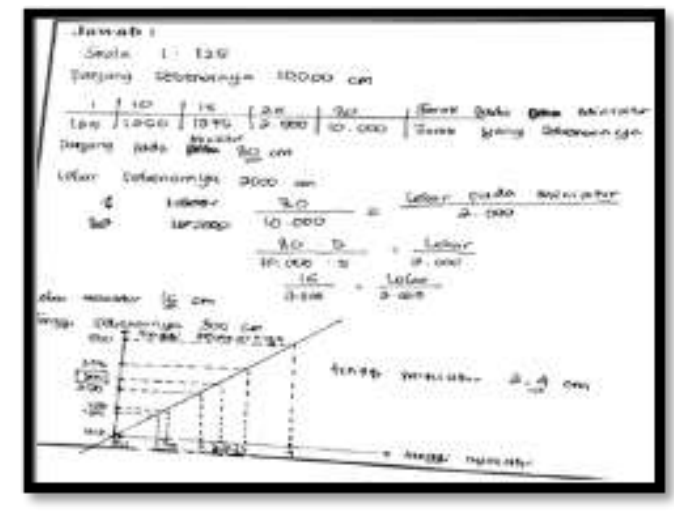

Figure 6. Results of high ability student answers to problem 2

From the Figure 6, high ability students can answer all the questions correctly from the problem. Student uses tables, comparisons and graphs to solve the problem. The first thing students do is look for the length of the Limas house using a table, and after that students use the proportion of the length and width to determine the width of the Limas house miniature, because the students know that between length and width have such an easy to be known. Then to determine the height of the miniature limas house, students determine it in a graph because students know the result will be between numbers 2 and 3 so that he chooses to use the graphical method.

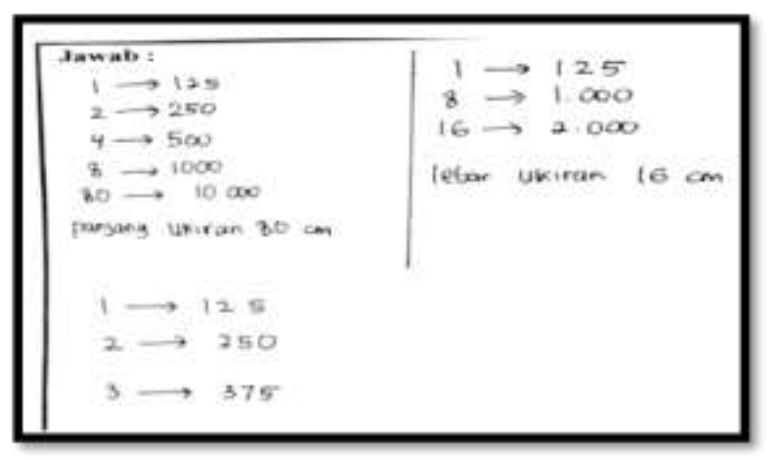

Figure 7. The results of the moderate students' answers on problem 2

From the Figure 7, moderate ability students can only determine the length and width of the Limas house miniature, and students do not seem to answer the question about the height of the Limas house miniature. Students uses the way the table is represented by the arrow symbol. The first thing students do is look for the length of the limas home carving using tables by calculating the proportion of $1,2,4,8$, and 80 . Then for the width of the limas home carvings because students have known that $8 \mathrm{~cm}$ inherits $1000 \mathrm{~cm}$ then he immediately knows 2,000 cm represented by $16 \mathrm{~cm}$. However, in looking height of Limas house is such as difficulty for students from the answers who stopped at numbers 1,2 , and 3. 


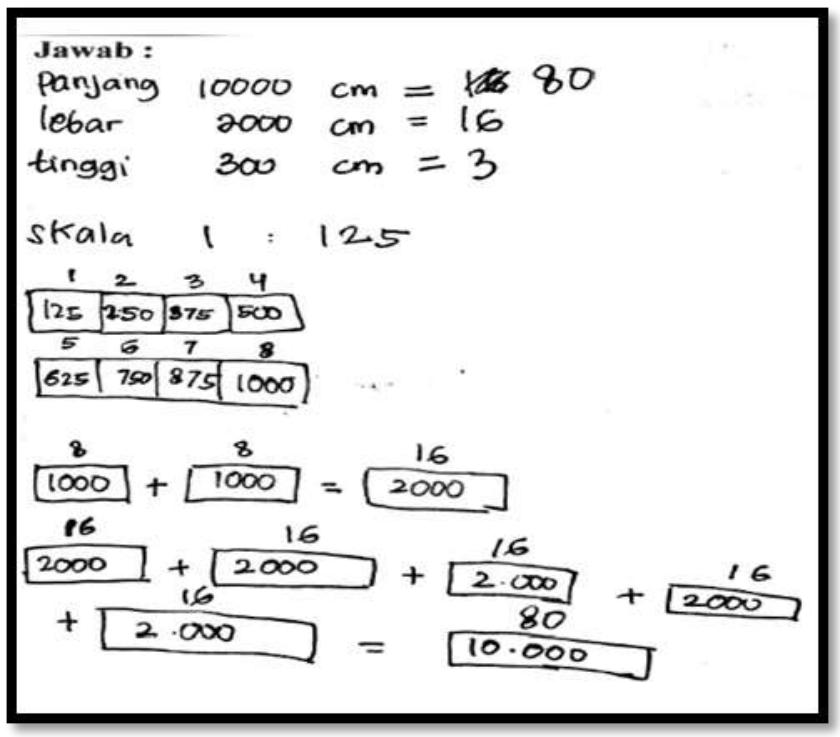

Figure 8. The results of low ability students' answers on problem 2

From the Figure 8, low ability students also can only determine the length and width of the Limas house miniature, and students look wrong in answering questions about the height of the Limas house miniature. Students uses the tabular method represented by a box shape. The first thing students do is look for proportion ranging from 1 to 8 , and find that $8 \mathrm{~cm}$ represents $1000 \mathrm{~cm}$. So to determine the width of the miniature, the students add up to $8 \mathrm{~cm}$ and $8 \mathrm{~cm}$ to get $2,000 \mathrm{~cm}$. After that, students know that $1 \mathrm{~cm}$ represents $125 \mathrm{~cm}$ is proportional to $16 \mathrm{~cm}$ represents $2,000 \mathrm{~cm}$, then the width of the miniature Limas house is $16 \mathrm{~cm}$. After the student knows that $16 \mathrm{~cm}$ represents $2,000 \mathrm{~cm}$, he adds $16+16+16+16+16$ to get the value of $10,000 \mathrm{~cm}$. So students can determine the length of the miniature limas house is $80 \mathrm{~cm}$. However, to determine the height of a miniature limas house, there was an error made by the student who answer $3 \mathrm{~cm}$. For low-ability students, the problem is a difficult problem that he is unable to do so the researcher gives him scaffolding at each step so that the student can answer the problem correctly and can understand it.

Overall from the second problem, high, medium, and low ability students can answer correctly to determine the length and width on a miniature of the actual scale and size. However, to determine the height of a miniature limas house, students of medium and low abilities were still wrong in completing it. This question can measure the ability of students to apply the concepts and procedures of proportion. This problem in bloom taxonomic level is called a matter of application (C3) and also called a problem of sharing tasks because almost all students can answer correctly from all questions of the problem. The three abilities of students have various and correct answers as students solve the problem through tables, arrow symbols, boxes and graphs. 


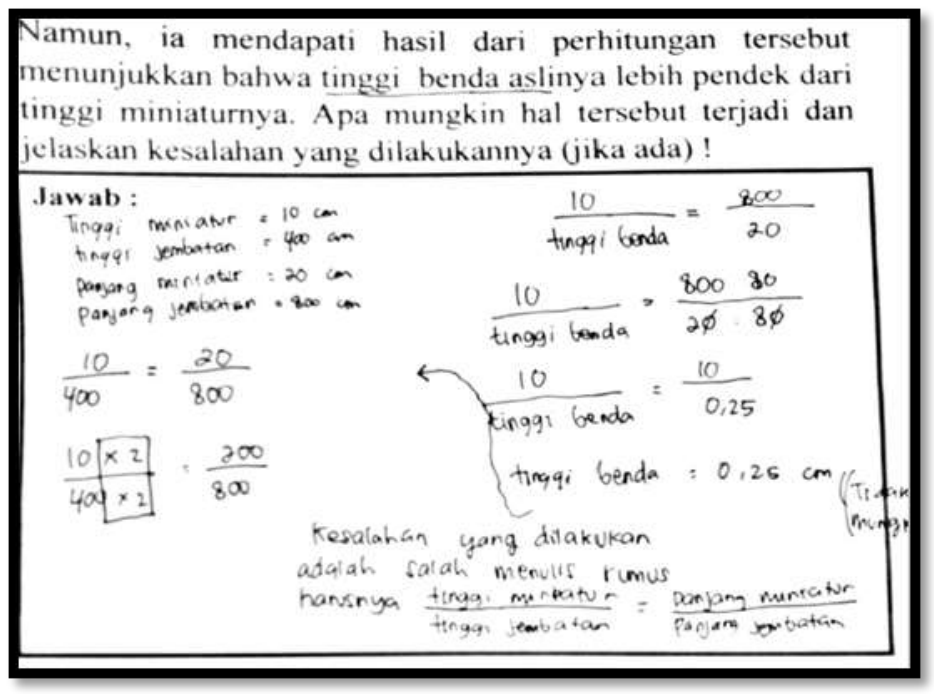

Figure 9. Results of high ability students' answers to problem 3

For high-ability students there is no difficulty in answering these problems because it looks like students take the measurements of height and length on miniatures and bridges then students try the formulas available on the problem so that students know what errors are contained in the question.

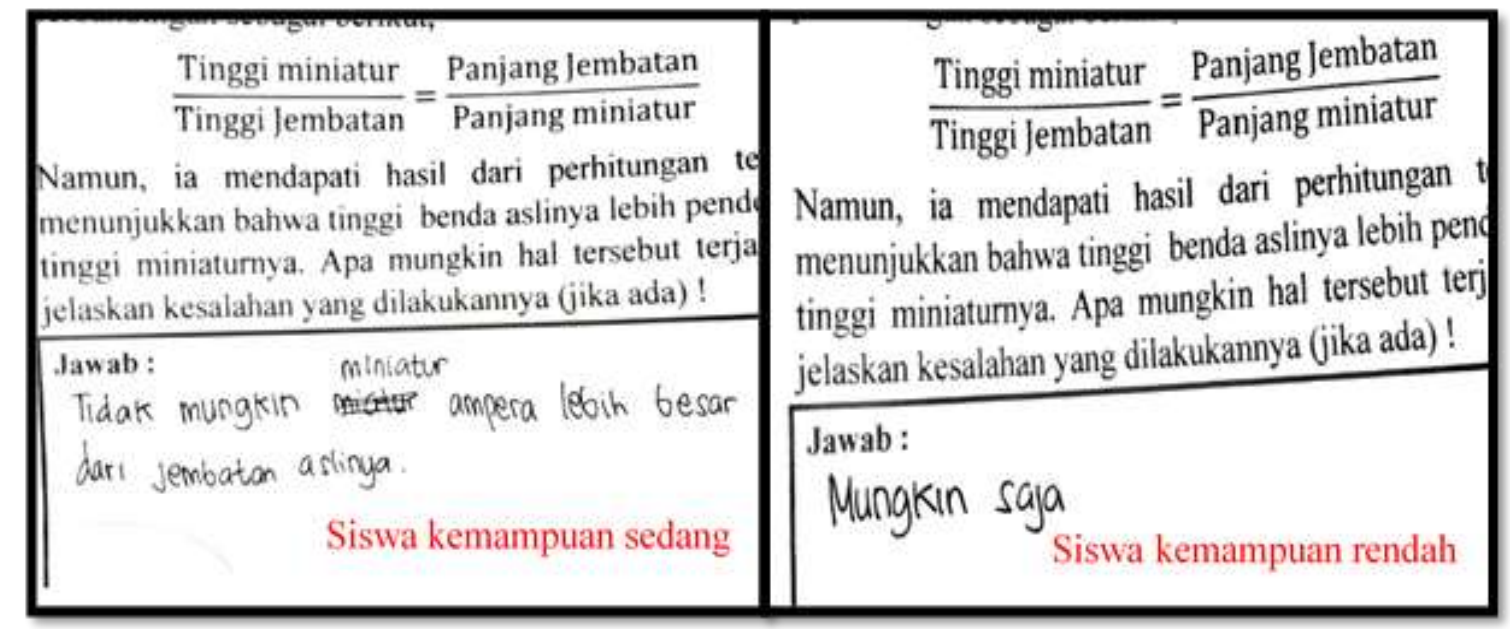

Figure 10. The results of students' answers on moderate and low ability on problem 3

For the medium ability, she knows that it is not possible but she can't give the right reason and can't find the mistake of what happened to the statement in question. For students of low ability, it is not correct answer to solve the problem. They do not understand that the ampera bridge miniature will not be larger in size than the original Ampera Bridge, so students' abilities in logic still lack. So the researchers gave him scaffolding in answering these problems so they could understand them.

Overall from the third problem, only high ability students can answer correctly to find out the mistakes that occur in these problems. But for students of moderate and low ability, they are still lack of reasoning that the miniature size of the Ampera Bridge will not be larger than the actual size. This question can measure the ability of students to test the truth of a statement. This problem in bloom taxonomy level is

IJEME, Vol. 3, No. 2, September 2019, 177-190. 
called a question of analysis (C4) and also called a problem of jumping tasks because almost all students cannot answer correctly from all questions of the problem.

After implementing one to one, the researcher did not make any changes in terms of language, content, and construct because the three problems were sufficient in suitable with the level of ability and understanding of students in the school, and the problem could be categorized as easy-medium-difficult based on student answers from one to one. So that the problem can be used in class VII students of semester 2 on direct proportion material of map and model topic.

Overall it is seen from students ' answer that the role of Self developed models is a bridge for students from real situation to concrete situation or from informal mathematics to formal form which means students make their own in Solve the problem (Zulkardi, 2002). Almost all students complete the answer using informal strategies such as tables, graphs, equation, etc.

\section{Small Group}

Then, The LKPD is tested on a small group of 8 people and then divided into 2 groups, the distribution of groups was also based on the level of student ability. Here the researcher becomes a teacher and conducts the learning process in fit with the designed LKPD and tries out a validated LKPD, the LSLC system is used at this stage in completing the LKPD questions consist of sharing tasks and jumping tasks, the model teacher observes the small group process. The results of the answers to the small group are then analysed by the researcher.
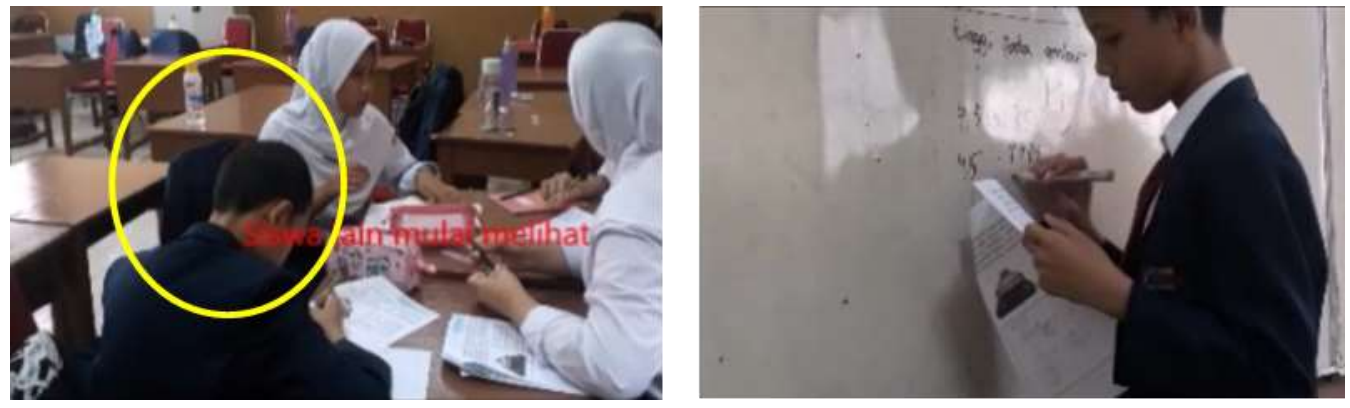

Figure 11. Student expressions in group 1
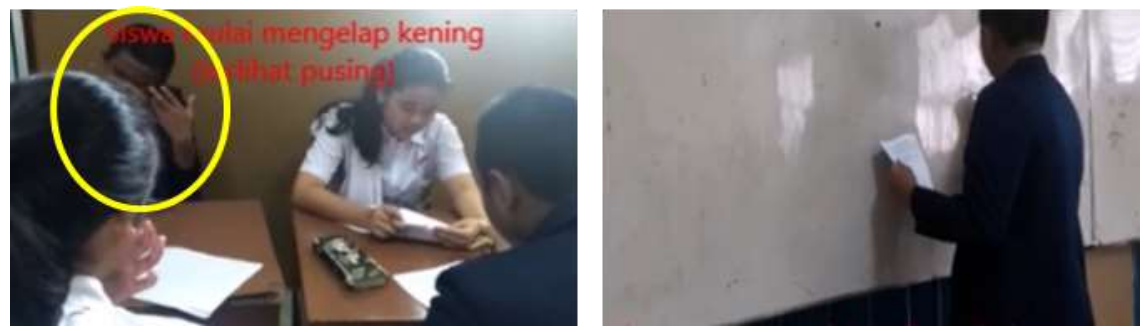

Figure 12. Student expressions in group 2

At the time of the atmosphere in a small group, the situation of class is quiet and focus on their respective LKPD, and when there are students who have difficulty in solving problems, they asks for help from their friends who can answer it, so it create a conducive classroom atmosphere and they do not riot in his group and their friend teaches students who have difficulty until they understand, then students who have difficulty say the word "thank you" to friends who have taught them. After that, 
students who have difficulty in each group are asked to come forward and present the results of their answers to the class. From these, it will create the learning atmosphere desired by researchers, which are students who have a caring nature to their friends who are having difficulties, students who value their friends by saying "please teach me" and the word "thank you" when asking for help from their friends so that they will arise mutual respect for each other, then the nature of the responsibility of students who ask to be taught by their friends to present the results of the answers so that researchers can understand the extent of student understanding in what his friend explained, and also with this atmosphere there are no more students who do not learn during class time because all students can help each other in the study group which makes students no longer get score of 0 when completing their respective worksheet.

Table 1. Recapitulation of student answers

\begin{tabular}{|c|c|c|c|c|}
\hline \multicolumn{5}{|c|}{$\begin{array}{l}\text { HASIL JAWABAN SISWA } \\
\text { Sharing Task }\end{array}$} \\
\hline 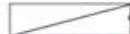 & 1 & $2><$ & 3 & Mata-rata \\
\hline P1 (L) & 100 & 80 & 60 & 80 \\
\hline S1 (P) & 100 & 60 & 20 & 60 \\
\hline S1 (P) & 100 & 40 & 10 & 5o \\
\hline R1 (L) & 100 & 30 & 20 & 50 \\
\hline$P 2(P)$ & 100 & 60 & 40 & 67 \\
\hline S2 (P) & 100 & 60 & 20 & 60 \\
\hline S2 (L) & 100 & 30 & 20 & 50 \\
\hline$R 2(L)$ & 100 & 30 & 10 & 47 \\
\hline Rata-rata & 100 & 49 & 25 & \\
\hline \multicolumn{2}{|c|}{$\begin{array}{l}\text { Keterangan : } \\
1=\text { Permasalahan } 1 \\
\text { P = Pintar }\end{array}$} & \multicolumn{2}{|c|}{$\begin{array}{l}2=\text { Permasalahan } 2 \\
\mathrm{~S}=\text { Sedang }\end{array}$} & $\begin{array}{l}3=\text { Permasalahan } 3 \\
R=\text { Rendah }\end{array}$ \\
\hline
\end{tabular}

In the Table 1, problem 1 has an average student score of 100, it shows that problem 1 is a question of sharing tasks where all students can answer the question, then problem 2 includes a question of sharing tasks with an average score of students is 49 , and problem 3 is a question of jumping assignments because the average student score is 25 . But with the collaboration created from each study group, students no longer have students who do not answer at all or are blank. So the average score obtained by each student include high-skilled students is 73.5, moderate-ability students are 55 , and low-ability students are 48.5 .

\section{CONCLUSION}

The conclusions of this research are, (1) the process of LSLC, Problem based learning, Collaborative Learning, PMRI Approach and Design Research are the right series of learning to be used in learning at SMPN 1 Palembang; (2) during the learning process takes place, using context in daily life can be recognized by students help them easier to solve problems of direct proportion material of map and model topic; (3) with students' understanding of scale material that has been taught in class $V$ can facilitate students in completing or understanding direct proportion material of map and model topic; (4) overall, after testing the research, students were greatly helped to solve direct proportion material of map and model topic; (5) problems 1 and 2 including sharing task, and problem 3 including jumping task. 


\section{REFERENCES}

Afri, L. E. (2015). Pengaruh Penerapan Metode Collaborative Learning terhadap Hasil Belajar Matematika Siswa Kelas VIII SMP Negeri 3 Rambah Samo. Jurnal Ilmiah Mahasiswa FKIP Prodi Matematika, 1(1).

Asari, S. (2017). Sharing and jumping task in collaborative teaching and learning process. DIDAKTIKA: Jurnal Pemikiran Pendidikan, 23(2), 184-188.

Basaria, N. \& Leonard. (2018). Model pembelajaran quantum learning dengan strategi pembelajaran tugas dan paksa. Prosiding Seminar Nasional dan Diskusi Panel Multidisiplin Hasil Penelitian dan Pengabdian kepada Masyarakat, 2 Agustus 2018, 274-287. ISBN: 978-602-50181-5-2.

Dayana, M., Jaya, M., \& Haenilah, E. (2015). Pengaruh Aktivitas Pembelajaran dengan Metode Collaborative Learning terhadap Perkembangan Sosial Emosional Anak. Jurnal Pendidikan Anak, 1(2): 2-14.

Dole, S., Wright, T., Clarke, D., \& Campus, P. (2009). Proportional Reasoning: Making Connections in Science and Mathematics (MCSAM), 1-18. Queensland, Australia: The University of Queensland.

Fiana, R. O., Relmasira, S. C., \& Hardini, A. T. A. (2019). Perbedaan Penerapan Model Project Based Learning Dan Problem Based Learning Terhadap Hasil Belajar Matematika Kelas 4 Sd. Jurnal Basicedu, 3(1), 157-162..

Gazali, R. Y. (2016). Pembelajaran matematika yang bermakna. Math Didactic: Jurnal Pendidikan Matematika, 2(3), 181-190.

Hapsari, D. I., \& Airlanda, G. S. (2019). Penerapan project based learning untuk meningkatkan motivasi belajar matematika. Jurnal Riset Teknologi dan Inovasi Pendidikan (JARTIKA), 2(1), 102-112.

Hasanah, A. F., Wibowo, L. A., \& Pardede, L. R. (2019, February). Modifikasi Model Pembelajaran Matematika Collaborative Learning Dengan Strategi Tugas dan Paksa. In Prosiding Seminar Nasional Pendidikan KALUNI (Vol. 2).

Kemdikbud. (2013). Kerangka Dasar dan Struktur Kurikulum 2013. Jakarta. Kemendikbud.

Kemdikbud. (2013). Lampiran Peraturan Menteri Pendidikan dan Kebudayaan No. 66 tahun 2013 tentang Standar. Jakarta: Kemendikbud.

Lakkiran, D. (2016). Peningkatan kualitas pembelajaran matematika siswa dalam materi segi empat melalui model kooperatif tipe Team Games Tournament (TGT) terintegrasi teori dienes dengan pendekatan saintifik pada kelas VII-A SMP Negeri 1 Tawalian Kabupaten Mamasa. Daya Matematis: Jurnal Inovasi Pendidikan Matematika, 3(3), 379-386.

Lewis, C. (2002). Does Lesson Study Have a Future in the United States?. Nagoya journal of education and human development.

Octarina, Putri, RII., \& Nurjannah. (2018). Analysis of Collaborative Culture Improvement through Lesson Study for Teacher. Proceeding International Conference on Lesson Study. Bogor

Paryanto, P. (2010). Penerapan Metode Pembelajaran Kolaboratif Tipe Group Investigation untuk Meningkatkan Kualitas Pembelajaran Teori Pemesinan Dasar. Jurnal Pendidikan Teknologi dan Kejuruan, 19(2), 169-194.

Patahuddin, S. M., \& Rokhim, A. F. (2009). Website permainan matematika online untuk belajar matematika secara menyenangkan. Jurnal pendidikan matematika, $3(2)$.

Putri, RII. (2018). Soal Hots dalam Jumping Task. Sumbar: Prosiding Seminar Nasional STKIP PGRI, 4(1): 9-18. 
Putri, R. I. I., Dolk, M., \& Zulkardi, Z. (2015). Professional development of PMRI teachers for introducing social norms. Journal on Mathematics Education, 6(1), 1119.

Primadiati, I. D., \& Djukri, D. (2017). Pengaruh model collaborative learning terhadap peningkatan motivasi dan hasil belajar IPA siswa kelas IV SD. Jurnal Prima Edukasia, 5(1), 47-57.

Rosliana, I. (2019). Pengembangan LKPD Matematika dengan Model Learning Cycle 7e Berbantuan Mind Mapping. Jurnal Pengembangan Pembelajaran Matematika, 1(1).

Sato, M. (2014). Dialog dan kolaborasi di sekolah menengah pertama praktek "learning community". Jakarta: Pelita.

Sembiring, R., Hoogland, K., \& Dolk, M. (2010). A Decade of PMRI in Indonesia. Utrecht: APS

Suwarni, S. (2017). Peningkatan Hasil Belajar Perbandingan dan Skala melalui Pembelajaran Matematika Realistik. Briliant: Jurnal Riset dan Konseptual, 2(1), 5865.

Tessmer, Martin. (1993). Planning and Conducting-Formative Evaluations. London, Philadelphia: Kogan Page.

Utari, R. S., Putri, R. I. I., \& Hartono, Y. (2015). Konteks Kebudayaan Palembang untuk Mendukung Kemampuan Bernalar Siswa SMP pada Materi Perbandingan. Jurnal Didaktik Matematika, 2(2).

Van den Akker, J. (1999). Principles and methods of development research. In Design approaches and tools in education and training (pp. 1-14). Springer, Dordrecht.

Wahyuni, N. D., \& Jailani, J. (2017). Pengaruh pendekatan matematika realistik terhadap motivasi dan prestasi belajar siswa SD. Jurnal Prima Edukasia, 5(2), 151159.

Widyastuti, W., Rumite, M., \& Marpaung, R. R. T. (2019). Minat Siswa Terhadap Matematika dan Hubungannya dengan Metode Pembelajaran dan Efikasi Diri. Jurnal Pendidikan Matematika, 13(1), 83-100.

Zulkardi. (2002). Developing A Learning Enviroment on Realistics Mathematics Education for Indonesian Student Teacher. Enschede: University of Twente.

Zulkardi, Z., \& Putri, R. I. I. (2010). Pengembangan blog support untuk membantu siswa dan guru matematika Indonesia belajar pendidikan matematika realistic Indonesia (PMRI). Jurnal inovasi perekayasa pendidikan (JIPP), 2(1), 1-24. 